Errata

\title{
A mutant of Chlamydomonas reinhardtii altered in the transport of ammonium and methylammonium
}

\author{
A.R. Franco, J. Cárdenas, and E. Fernández \\ Departamento de Bioquimica, Facultad de Ciencias, Universidad de Córdoba, E-14071 Córdoba, Spain
}

Mol Gen Genet (1987) 206:414-418

The complete reference should read:

Cullimore JV, Sims AP (1981) Pathway of ammonia assimilation in illuminated and darkened Chlamydomonas reinhardii. Phytochemistry $20: 933-940$

\section{The expression of a chimeric soybean beta-tubulin gene in tobacco}

Mark J. Guiltinan ${ }^{1}$, Jeff Velten ${ }^{2}$, Mauricio M. Bustos ${ }^{1}$, Richard J. Cyr ${ }^{1}$, Jeff Schell $^{2}$, and Donald E. Fosket ${ }^{1}$

${ }^{1}$ University of California, Irvine, CA 92717, USA

${ }^{2}$ Max-Planck-Institut für Züchtungsforschung, D-5000 Köln 30, Federal Republic of Germany

Mol Gen Genet (1987) 207:328-334

On page 328 , the last paragraph in the second column should read:

The soybean haploid genome contains two classes of beta tubulin genes. 